\title{
El sexto sentido de M. Night Shyamalan. ¿Algo más que su sorprendente final?
}

\author{
Mireia Maldonado Parra \\ Universidad de Sevilla \\ mireia16397@gmail.com \\ https://dx.doi.org.10.12795/futhark.2017.il 2.04
}

Fecha de recepción: 10.09.2017

Fecha de aceptación: 15.11.2017

Resumen: De El sexto sentido de M. Night Shyamalan se destaca habitualmente el giro o "plot twist" que supone su sorprendente final. Sin embargo, como demostrará el presente artículo, el final de la cinta cuenta con numerosos antecedentes en el mundo del cine, incluso no reciente, y su verdadero valor ha de situarse más bien en la multiplicidad de interpretaciones que ofrece. El presente artículo pretende mostrar parte de esta diversidad presentando interpretaciones y análisis de críticos que saben encontrar en la película su capacidad de abordar cuestiones existenciales muy profundas.

Palabras clave: El sexto sentido, Shyamalan, Thriller, plot twist, narración cinematográfica.

\section{Night Shyamalan's The Sixth Sense: more than a surprising ending?}

\begin{abstract}
From M. Night Shyamalan's The Sixth Sense scholars usually highlight its plot twist, which leads to its surprising ending. However, as the present article will show, the end of this film has many antecedents in the world of cinema. Its true value has to be placed rather in the multiplicity of interpretations which can be offered. This article aims to portray part of this diversity by presenting interpretations and analyses from critics who know how to find in the film its ability to approach very deep existential questions.
\end{abstract}

Key words: The sixth sense, Shyamalan, Thriller, plot twist, cinematic narration. 
En el año 1999 la película El sexto sentido (The Sixth Sense) del director indioestadounidense M. Night Shyamalan' alcanzó el puesto número dos en el ranking de éxitos de taquilla ${ }^{2}$, hecho que resulta especialmente destacable si tenemos en cuenta que sólo fue superada por el primer episodio de la saga Star Wars ${ }^{3}$ de George Lucas. Y no sólo consiguió despertar el interés del público, sino que también la crítica se dejó atrapar por la película. Miller la considera "far the most commercially successful ghost film of recent years" (Miller 2007: II3), e insiste en que "Shyamalan's work has been incredibly popular, attracting widespread media attention, and even eliciting fairly nuanced academic treatment." (Miller: op.cit). The Sixth Sense llegó a tener seis nominaciones en la $72^{\circ}$ Edición de los Óscar, dos en la $57^{\mathrm{a}}$ Edición de los Globos de oro ${ }^{6}$, cuatro en la $53^{\mathrm{a}}$ Edición de los $\mathrm{BAFTA}^{7}$, y uno en la $6^{a}$ entrega de los Premios del Sindicato de actores.

En cuanto al público, es posible que gran parte de los espectadores se interesara y acudiera a ver la película gracias a que en ella actuaba Bruce Willis ${ }^{8}$, actor ya consagrado que también había protagonizado el número dos de taquilla del año anterior, Armageddon (1998), de Michael Bay, una película de ciencia-ficción y catástrofe futurista, en la que el actor americano interpretaba un papel heroico

\footnotetext{
' M. Night Shyamalan nació en Mahé, Pondicherry (India) el 6 de agosto de 1970, aunque creció en Penn Valley, Pennsylvania, (Estados Unidos). (https://www.filmin.es/director/m-night-shyamalan Consultado por última vez el 16.04.17).

${ }^{2}$ Según Box Office Mojo recaudó \$293,506,292. También es una de las 25 películas más taquilleras de la historia (https://www.boxofficemojo.com/movies/?id=sixthsense.htm Consultado por última vez el 16.04.17). Foust afirma que "The Sixth Sense was the second highest- grossing film of 1999, behind only Star Wars: Episode I (“\$100 Million Movies,” 2002)” (Foust 2006:I I6).

${ }^{3}$ Star Wars siempre ha tenido impresionante éxito de taquilla, tal y como muestra Box Office Mojo. El segundo episodio, de hecho, también estuvo entre los primeros puestos en la taquilla de su año de estreno, 2002. (https://www.boxofficemojo.com/yearly/chart/?view2=worldwide\&yr=2002\&p=.htm Consultado por última vez el 16.04.17).

${ }^{4}$ Briefel indica que se trata de "the most famous cinematic narrative of spectral incognizance" (Briefel 2009: 95).

${ }^{5}$ Mejor película; mejor director; mejor actor de reparto: Haley Joel Osment; mejor actriz de reparto: Tony Collette; mejor guion original: M. Night Shyamalan; mejor montaje: Andrew Mondshein. No lograron llevarse ninguno a casa. (https://www.oscars.org/oscars/ceremonies/2000 Consultado por última vez el 16.04.17).

6 Mejor actor de reparto: Haley Joel Osment; mejor guion: M. Night Shyamalan. (https://www.digitalhit.com/golden-globe-awards/57th/nominations/ Consultado por última vez el 16.04.17).

7 Mejor película; mejor director; mejor guion original; mejor montaje. (http://awards.bafta.org/award/2000/film Consultado por última vez el 16.04.17).

${ }^{8}$ Owszarski menciona el protagonismo de Willis en la publicidad de la película (Owszarski 20I0: I30),
} 
muy en la línea de algunos de sus trabajos anteriores ${ }^{9}$. The Sixth Sense le proporcionaría a Willis un giro muy positivo a su carrera, le ayudó a ser considerado algo más que un actor sólo apto para el cine de acción y le permitió aparecer en películas más ambiciosas, como la independiente Alpha Dog (2006) de Nick Cassavetes, Sin City $(2005)^{10}$, de Robert Rodríguez y Frank Miller o también, años más tarde, Unbreakable (2000) ${ }^{11}$ del propio Shyamalan ${ }^{12}$.

No obstante, pese al innegable atractivo de Willis, el verdadero favor del público lo obtuvo Haley Joel Osment, de entonces II años de edad, que dejó fascinados a todos con una soberbia actuación. Osment, que ya había participado anteriormente en varias películas ${ }^{13}$, e incluso había estado presente en alguna serie de televisión ${ }^{14}$, logró entrar por la puerta grande de Hollywood gracias a este papel, hasta el punto de que sólo un año más tarde se le volvió a ofrecer la actuación protagonista en Pay it Forward ${ }^{15}$ (2000) de Mimi Leder, y también al siguiente repitió con A.I. Artificial Intelligence (200I) a las órdenes de Steven Spielberg ${ }^{16}$

Hay que conceder, sin embargo, en que en The Sixth Sense encontramos mucho más que el gran trabajo de dos magníficos actores, muestra de lo cual es que algunas de sus escenas más destacadas forman parte ya del imaginario

\footnotetext{
9 Die Hard (1988) (https://www.filmaffinity.com/es/film38535I.html Consultado por última vez el 16.04.17).

10 Adaptación de un famoso cómic Sin City (1992, Editorial Dark Horse) (https://www.goodreads.com/book/show/392297.Sin_City_Vol_I Consultado por última vez el 16.04.17). Willis se dedicaría al mismo tema en Unbreakable.

1 Traducida como El protegido al castellano. (https://www.filmaffinity.com/es/film I 36438.html Consultado por última vez el 16.04.17).

12 Willis siguió haciendo películas de acción. (https://www.imdb.com/name/nm0000246/ Consultado por última vez el 16.04.17).

13 Entre ellas destacan Forrest Gump (1994), Un día de locos (1994) y For Better or Worse (1995). (https://www.imdb.com/name/nm0005286/?ref_=nv_sr_I Consultado por última vez el 16.04.17).

14 Por ejemplo El show de Larry Sanders (1994) y Después de una guerra (1997). (https://www.imdb.com/name/nm0005286/?ref_=nv_sr_I Consultado por última vez el 16.04.17).

15 Traducida al castellano como Cadena de favores (https://www.imdb.com/title/tt0223897/?ref_=nv_sr_I Consultado por última vez el 16.04.17).

${ }^{16}$ Sin embargo, como ocurre con frecuencia con quienes entran en el mundo del cine a edades muy tempranas, su éxito quedó ahí, pese a que continuó participando en varias producciones más. Como caso similar se conoce el de Macaulay Culkin. (https://www.imdb.com/name/nm0000346/?ref_=nv_sr_I Consultado por última vez el 16.04.17).
} 
colectivo ${ }^{17}$. Como asegura Briefel, la película contiene, entre otras, "a line that has become a cultural cliché: "I see dead people." (Briefel 2009: 97). Y, sobre todo, su sorprendente final, ha sido objeto de múltiples discusiones $y$, debido al éxito comercial de la película, imitaciones ${ }^{18}$.

Además de permitir que el desconocido Shyamalan se convirtiera en uno de los cineastas más alabados de este siglo, el supuesto engaño ${ }^{19}$ al que se somete al espectador ha sido tema central de numerosos estudios científicos, considerándolo con frecuencia clave para asignarle su valor a la película, como, por ejemplo, hace Paik: "the thrill experienced by the audience at the conclusion of the film consists of the overturning of its spectatorial position ("the protagonist has been dead all along!") (Paik: 2003) o como también afirma Anderson "the film's implied author intends to fool us by suggesting through conventional editing and cinematography that Crowe has survived. (Anderson 2010: 88).

Sin embargo, recientemente muchos otros críticos reclaman que el valor de The Sixth Sense se encuentra mucho más allá de ese supuesto timo al espectador. Por una parte, el engaño del que siempre se ha hablado quizá no sea tal, pues no son pocas las señales que Shyamalan incluye en su cinta y que desde un primer momento nos indican qué le ocurre en realidad al personaje interpretado por Willis ${ }^{20}$, sólo que su relato está tan bien construido que no es fácil advertirlo. Kriesch habla de trucos, como, por ejemplo, el fundido en negro después del tiroteo del principio: "The black screen following the prologue is shown for ten (!)

\footnotetext{
17 Vid. la definición que contiene el urban dictionary: "I see dead people. A famous quote now used by many for mocking others. It originated from "The Sixth Sense" by M. Night Shyamalan. Cole Sear (Haley Joel Osment) said this line. The popularity of this line had grown, and now many people say things similiar to this, like how people always change the phrase "got milk?". Some examples of how it has canged are, "I see white people", "I see black people", or "I see naked people". (https://www.urbandictionary.com/define.php?term=i\%20see\%20dead\%20people Consultado por última vez el 16.04.17).

18 Vid: "The critical and economic success of The Sixth Sense caused a proliferation of films that depict either the afterlife from the point of view of the newly de-ceased, who have yet to discover that they are dead, or whose characters are dying, e.g., The Others (200I), Mulholland Dr (200I), Donnie Darko (200I), Soul Survi- vors (200I), Hellraiser: Hellseeker (2002), Dead End (2003), Lost Things (2003), November (2004), The I Inside (2004), The Jacket (2005), Stay (2005), Reek- er (2005), The Dark Hours (2005), The Descent (2005), The Abandoned (2006), Wind Chill (2007), The Deaths of lan Stone (2007), The Escapist (2008), Passengers (2008), No Man's Land: The Rise of Reeker (2008), Haunting of Winchester House (2009), Shadow (2009), and Wound (2010)." (Kriesch: sa: 73).

${ }^{19}$ Coats, que analiza The Village (2004) considera que el engaño es algo habitual en Shyamalan (Coats 2008: 360).

${ }^{20}$ Vid: "The narrator in The Sixth Sense underreports events-the event of Crowe's death-and then focalizes through Crowe as he misinterprets his experiences. In presenting the story through his skewed perspective, the film misleads the viewer without actually lying" (Anderson 2010: 90).
} 
seconds, which could suggest that Malcolm's recovery might take a very long time" (Kriesch 2016: 75). En este contexto es importante prestar atención a las pistas que proporciona el pequeño Cole, indicando claramente cuál es su peculiaridad: "I see dead people... Some of them scare me" (Shyamalan 1999: s. p.) ${ }^{21}$, y señalando características de sus visitantes especiales: "When they get mad, it gets cold" (Shyamalan 1999: s. p.) $)^{22}$, y, sobre todo, no saben que están muertos "Some of them don't know they're dead" (Shyamalan 1999: s. p.). Estas sutiles indicaciones se complementan con la incapacidad del psicólogo (Bruce Willis), para comunicarse con otras personas, o realizar tarea tan común como abrir puertas. Igualmente, Barrat cree esencial que cuando Cole pronuncia su famosa frase, la cámara enfoca a Malcolm (Barrat 2009: 62).

Por supuesto, para hacer menos evidentes las señales estas han sido ligeramente oscurecidas. Shyamalan lleva conscientemente a la confusión con su habilidad por construir escenarios llenos de equívocos, como aquellas escenas en las que el psicólogo parece estar hablando con otras personas, como ya se ha mencionado. Igualmente, son significativas las escenas en las que el psicólogo se encuentra sentado frente a la madre del niño, aparentemente, pero sólo en apariencia, hablando con ella, o cuando acompaña a Cole y a su madre al médico, pero sin llegar a interactuar en realidad con ninguno de los personajes. Y quizá la escena más confusa en este sentido es aquella en la que el psicólogo está cenando con su esposa para celebrar su aniversario ${ }^{23}$.

Pero pese a todo, no podemos olvidar que las pistas para interpretar de forma adecuada -y no errónea, como hacen prácticamente todos los espectadores en un primer visionado- la película siempre han estado ahí, y aquí nos acercamos a uno de los valores principales de la película, no un mero final sorprendente, sino la multiplicidad de posibilidades de interpretación.

21 Las citas están sacadas del guion online que carece de paginación http://www.sellingyourscreenplay.com/wp-content/uploads/screenplay/scripts/The-Sixth-Sense.pdf

${ }^{22}$ Hace frío cuando está Bruce Willis como se demuestra en varias escenas.

${ }^{23}$ Vid aquí: "The commonality of this experience is conveyed through a montage of scenes playing on the trope of one's life flashing before one's eyes prior to death, with the important difference that here it is evidence of death rather than life that flashes before our eyes. These images compel the protagonist and spectators to notice what we have missed all along: moments that seemed to signal Malcolm's presence in conversations, rooms, and relationships actually designated his absence from them. Thinking back to his anniversary dinner with Anna, for example, we come to understand that she is not giving him the cold shoulder, as we had believed, but that she ignores him because he himself is cold-he is a ghost whose presence she fails to notice. Indeed, we realize that he does not interact with anyone except for Cole throughout the film. It becomes clear that the young boy's monologue about his unwanted special powers applies to Malcolm: "I see dead people . . . walking around like regular people. They don't see each other. They only see what they want to see. They don't know they're dead” (Briefel 2009: 101). 
Porque simplemente dar la vuelta a la historia para lograr un final que nadie espera es algo bastante común en el cine. Véanse aquí películas tan conocidas como Rebecca (1940) o Psycho (1960) de Hitchcock ${ }^{24}$. Otros finales, como por ejemplo el de la serie televisiva Los Serrano (2003-2008), producen una sorpresa no anticipada por el género más bien cómico del producto, pero resultan artificiales, le parecen al espectador un cierre sin sentido imaginado en el último momento ${ }^{25}$, y han recibido múltiples muestras de insatisfacción por parte de público y crítica. ${ }^{26} \mathrm{Y}$ muchos más son los ejemplos que se podrían citar aquí. Carnival of Souls (1962) de Herk Harvey tiene en común con The Sixth Sense a una protagonista que se encuentra entre la vida y la muerte. Chinatown (1974) de Roman Polanski vuelve a demostrar lo común que son los finales sorprendentes en el cine de misterio, y a estos ejemplos le podemos añadir películas más próximas a nuestros tiempos como The Usual Suspects (1995) de Bryan Singer, Seven (1995), de David Fincher, Mullholland Drive (200I) de David Lynch, Secret Window (2004), de David Koepp, The perfect Host (2010) de Nick Tommay, la coreana Old boy (2003) de Park Chan-Woon, y La piel que habito (20II) de Pedro Almodóvar, demostrando estos últimos que la técnica no sólo es propia del cine estadounidense.

The Sixth Sense va más allá. Como dice Miller:

Shyamalan's tendency to rely heavily on extremely manipulative identification techniques and his preference for gimmicky surprise endings or last-minute twists have tended to obscure his films' more significant content. (Miller 2007: II3).

$Y$ es que la cinta ofrece una multiplicidad de interpretaciones. Sherman destaca en ella que

The film is not so much about clearing up any particular local or domestic trauma, laying any particular unsettled soul to rest, but rather about establishing the need for commitment to obligation (Sherman 2007: 34).

insistiendo en que el verdadero valor de la película se halla en la resistencia del joven Cole a aceptar el destino para el que está llamado, y marginando aquí por completo la posible relevancia del impactante final. Precisamente, para Sherman el

${ }^{24}$ Donde sin embargo el género al que se circunscriben ambas, misterio y terror, ya anticipaban algún tipo de sorpresa, aunque se ignoraba cuál podría ser esta.

${ }^{25}$ No es el caso de Shyamalan, un director que demuestra con sus muchas señales que el final de su película estaba pensado desde los mismos inicios.

${ }^{26}$ Calificado como "uno de los cierres más vergonzosos de la historia de la televisión patria" por Fotogramas (https://www.fotogramas.es/series-tv-noticias/a 19472537/final-los-serrano-insultoespectador/) y como "una gran estafa" por La Vanguardia (https://www.lavanguardia.com/series/seriesespanolas/201807/7/45946259450/los-serrano-I0-aniversario-final-todo-era-un-sueno.html Consultadas por última vez el 16.04.17). 
amor del público por Haley Joel Osment no se debe tanto a su soberbia actuación, sino a la capacidad del espectador para captar, a través del niño, el mensaje implícito de la película: que en cuanto uno deja de huir de aquello para lo que está llamado ${ }^{27}$, se pierde el miedo y nace la posibilidad de ser feliz ${ }^{28}$. $Y$ es ese el final que realmente le importa a este crítico:

Strikingly, most reviews deliberately deemphasized Bruce Willis's star turn in favor of Haley Joel Osment's remarkable performance as the gifted child. I think that this reflects not only the quality of Osment's work but the ideological slant of the film: it focuses unerringly on the vocational crisis (Sherman 2007: 34).

Precisamente, la aceptación de Cole de cumplir con su destino de auxiliar de aquellos que no pueden ayudarse a sí mismos, invierte el papel de los personajes de la historia, y ya no es Malcolm (Willis) quien ayuda a Cole (Osment) a salir de la conflictiva situación psicológica en la que se encuentra, sino al revés. Mediante una leve sugerencia, es ahora Cole quien pone a Malcolm en el camino correcto para solucionar su problema más acuciante, en apariencia, su matrimonio, pero en realidad la aceptación del hecho de su muerte. Como indica Kriesch:

After Cole has learned to accept his sixth sense, he is able to tell his mother about his gift, which rebuilds their mutual trust. Additionally, he becomes the ghosts' counselor, which is highlighted by the fact that he advises Malcolm to talk to his wife in her sleep. (Kriesch 76). ${ }^{29}$

Aquí la película se interpreta pues como la insatisfacción que genera la no aceptación del propio destino. Ringstrom insiste en que:

M. Night Shyamalan's The Sixth Sense (1999) is about the terrifying consequences of being unwilling to look at critically important truths about oneself. The film also explores the trans- formative experience that ensues when one finally looks at those truths and actually grasps them. (Ringstrom 200I: 393).

Ringstrom va incluso más allá, y cree que la película no sólo debe interpretarse como nuestra resistencia a aceptar un destino que no nos place

\footnotetext{
${ }^{27}$ Perron 2012: 61 coincide con esta interpretación.

${ }^{28}$ Véase la escena al final en la que Cole charla animadamente con los muertos.

${ }^{29}$ Vid. también: Malcolm's knowledge about his actual identity and existence, his recognition of the paranormal, as well as his ability to finally communicate with his wife are all due to Cole. (Kriesch sa: 76) y a Ringstrom en: Cole's liberation now readies him to become his therapist's therapist. We begin to discover that 9-year-old Cole has an intuitive grasp of good analytic technique. Cole never directly tells his 'patient' Dr Crow, 'You are a ghost'. Instead, he deftly enables Crow to arrive at his own ineluctable conclusión (Ringstrom. 2001: 394).
} 
demasiado, sino incluso a la negación de nuestra mortalidad, $y$, por tanto, necesariamente, la de nuestra muerte. Así, afirma que:

Shyamalan, who does double duty as screenwriter and director, is a master illusion- ist. He understands that if you supply even the slightest detail of a desired version of reality, your audience will supply the rest. Wishes dic- tate what is seen; denial keeps the undesired at bay. Shyamalan keenly grasps that the latter corresponds with our collective denial of death, while the former reflects our wish for resurrection, or more simply put, to get a sec- ond chance. (Ringstrom 2001: 393).

El existencialismo es también la idea que percibe Foust: "its greater significance lies in its connections to the fundamental fears of our time". (Foust 2006: I16), aunque sitúa el miedo en un ámbito totalmente diferente al de los críticos anteriores, en la idea de identidad, y los peligros de la moderna sociedad de consumo: "the film reinforces the idea that it is through a professional identity that one may comfortably manage the trauma of having one's existence called into question". (Foust 2006: II5).

Un mensaje completamente distinto, muy alejado del determinismo de Sherman, y la filosofía de Ringstrom cree advertir como prioritario Paik, que nos dice que:

What these films seek to accomplish, whether by therapeutic ministrations or by the realization that death bridges two extensions of monotonous life, is the domestication of what Zizek, following Kierkegaard, calls the "ultimate horror," which is not death but the inability to die. (Paik 2003).

conectando aquí The Sixth Sense con la última moda de relatos de zombis, en los que estos dejan de ser meros espantapájaros de pesadilla para permitir la reflexión sobre una posible humanidad latente o perdida, como ocurre, por ejemplo en The Walking Dead, o, en el plano de la literatura, en Graues Land de Oliver Dissieux.

Martin, en cambio, que menciona The Sixth Sense muy brevemente, la considera especialmente significativa subrayando sus "virtues of suggestive horror over graphic violence"30 (Martin 2009: 36), y la sitúa en el mismo grupo que películas aparentemente tan dispares como The Blair Witch Project (1999) de Daniel Myrick and Eduardo Sánchez o The Ring (2002), de Gore Verbinski.

Por lo tanto podemos concluir que El sexto sentido es mucho más que su sorprendente final, dando pie a numerosas interpretaciones por parte de diversos teóricos. Es difícil llegar a un consenso en cuanto a qué significa realmente el final de la película, algo que en un principio puede parecer en cierto modo superficial. $A$

${ }^{30}$ Vid. así mismo "The Sixth Sense offered restraint where Scream had offered glossy violence". (Martin 2009: 34 . 
pesar de ello, muchos investigadores coinciden en que es una película que esconde un significado mucho más profundo, siendo un claro ejemplo de una historia de superación y de la búsqueda de la propia identidad.

\section{Referencias bibliográficas}

Anderson, E. R. (20I0). Telling Stories: Unreliable Discourse, Fight Club, and the Cinematic Narrator. Journal of Narrative Theory 40(I): 80-107. Eastern Michigan University. Retrieved February 12, 2019, p. 83. from Project MUSE database.

Barratt, D. (2009). "Twist Blindness”: The Role of Primacy, Priming, Schemas, and Reconstructive Memory in a First-Time Viewing of The Sixth Sense. Puzzle Films, 62.

Briefel, A. (2009). What Some Ghosts Don't Know: Spectral Incognizance and the Horror Film. Narrative 17(I), 95-108. The Ohio State University Press. Retrieved February 12, 2019, from Project MUSE database

Coats, L., Cohen, M., Miles, J. D., Nishikawa, K., \& Walsh, R. (2008). Those We Don't Speak Of: Indians in The Village. PMLA, I23(2): 358-374.

Foust, C. R., \& Soukup, C. (2006). Do I Exist?: Transcendent Subjects and Secrets in The Sixth Sense. Western Journal of Communication, 70(2): II5-I33.

Kriesch, D. 'They only see what they wanna see': Traumatised Ghosts and Ghost Story Conventions in The Sixth Sense and The Others. ALPH, 7I: p.73.

Martin, D. (2009). Japan's" Blair Witch": Restraint, Maturity, and Generic Canons in the British Critical Reception of" Ring". Cinema Journal: 35-5I.

Miller, J. (2007). "Now That I Have It, I Don't Want It": Vocation and Obligation in Contemporary Hollywood Ghost Films. In Sherman S. \& Koven M. (Eds.), Folklore/Cinema: Popular Film as Vernacular Culture. Logan, Utah: University Press of Colorado, II3-128.

Owczarski, K. (2010). Reshaping the Director as Star. In Critical Approaches to the Films of M. Night Shyamalan. Palgrave Macmillan, New York, II9-I 35.

Paik, P. Y. (2003). Smart Bombs, Serial Killing, and the Rapture: The Vanishing Bodies of Imperial Apocalypticism. Postmodern Culture I4(I), Johns Hopkins University Press. Retrieved February 12, 2019, from Project MUSE database

Perron, B. (20I2). Silent hill: The terror engine. University of Michigan Press.

Ringstrom, P. A. (200I). The sixth sense. The International Journal of Psychoanalysis, 82(2): 393-395.

Sherman, Sharon R. and Koven, Mikel J., "Folklore/Cinema: Popular Film as Vernacular Culture" (2007). All USU Press Publications. 34.

Shyamalan, M. N., Willis, B., Osment, H. J., Collette, T., \& Williams, O. (2000). The sixth sense. PlazaVista. 


\section{-Webgrafía}

https://www.boxofficemojo.com/movies/?id=sixthsense.htm

https://www.boxofficemojo.com/yearly/chart/?view2=worldwide\&yr=2002\&p=.htm https:/www.digitalhit.com/golden-globe-awards/57th/nominations/

bafta.org/award/2000/film

https:/www.filmin.es/director/m-night-shyamalan

https://www.filmaffinity.com/es/film I 36438.html

https://www.filmaffinity.com/es/film38535I.html

https://www.fotogramas.es/series-tv-noticias/a 19472537/final-los-serrano-insultoespectadorl

https://www.goodreads.com/book/show/392297.Sin_City_Vol_I

https://www.oscars.org/oscars/ceremonies/2000

https://www.imdb.com/name/nm0000246/

https://www.imdb.com/name/nm0000346/?ref_=nv_sr_I

https://www.imdb.com/name/nm0005286/?ref_=nv_sr_I

https://www.imdb.com/title/tt0223897/?ref_=nv_sr_I

https://www.lavanguardia.com/series/series-espanolas/201807I7/45946259450/losserrano-I0-aniversario-final-todo-era-un-sueno.html

http://www.sellingyourscreenplay.com/wp-content/uploads/screenplay/scripts/TheSixth-Sense.pdf

https://www.urbandictionary.com/define.php?term=i\%20see\%20dead\%20people 